\title{
The Benefits of Water Hyacinth (Eichhornia crassipes) for Southern Africa: A Review
}

\author{
Obianuju P. Ilo ${ }^{1, * \mathbb{C}}$, Mulala D. Simatele ${ }^{2}\left(\mathbb{D}, \mathrm{S}^{\prime}\right.$ phumelele L. Nkomo ${ }^{1}$, \\ Ntandoyenkosi M. Mkhize ${ }^{3}$ (D) and Nagendra G. Prabhu ${ }^{2,4}$ \\ 1 Discipline of Geography, College of Agriculture, Engineering and Science, University of KwaZulu-Natal, \\ Durban 4041, South Africa; NkomoS1@ukzn.ac.za \\ 2 Global Change Institute, University of the Witwatersrand, Johannesburg 2050, South Africa; \\ Mulala.Simatele@wits.ac.za (M.D.S.); prabhugn@sdcollege.in (N.G.P.) \\ 3 Discipline of Chemical Engineering, College of Agriculture, Engineering and Science, University of \\ KwaZulu-Natal, Durban 4041, South Africa; MkhizeN7@ukzn.ac.za \\ 4 Centre for Research on Aquatic Resources, S. D. College, University of Kerala, Alleppey, Kerala 688003, India \\ * Correspondence: u.jblige@yahoo.com
}

Received: 4 September 2020; Accepted: 6 October 2020; Published: 6 November 2020

check for updates

\begin{abstract}
Globally, water hyacinth is a known invasive species that predominantly threatens the pillars of sustainability. The cost of controlling these invasive plants is high and many Southern African countries are barely equipped for this liability as the process has to be performed over time. Despite this challenge, there is valuable resource recovery from water hyacinth which can be used to make financial and environmental returns. The visible differences between the control and utilisation methods lie in the definition, recognition, and matching of costs and benefits. Using a rapid appraisal of existing literature, which was analysed using meta-analysis, the current paper is an attempt to discuss the beneficial use of water hyacinth. It is argued in the paper that the economic feasibility of control methods which, on one hand, are used to calculate the economic value of water hyacinth, mainly relies on assumptions whose reliability and sustainability are questionable, thus implying limitations on using this kind of control methods. On the other hand, the costs and benefits of utilising water hyacinth can be quantifiable, making them susceptible to changes associated with time value and sensitivity analysis of possible fluctuations in cashflows. In the context of these annotations, other scholars have argued for the consideration of other utilisation alternatives, among which is included biogas which has been identified as the most viable option because of its potential in diversifying the energy mix, reducing greenhouse gas emissions, and contributing to improved water quality. Given these observations, this paper aims to contribute to policy and research discussions on the fiscal understandings of the material recovery from water hyacinth to promote the adoption of biogas technology. These views are discussed within the broader discourse of the sustainable development goals (SDGs).
\end{abstract}

Keywords: water hyacinth; biomass; control; utilisation; bioenergy; cost-benefit; Southern Africa

\section{Introduction}

Water hyacinth, commonly identified as Eichhornia crassipes, is a destructive invasive alien species (IAS) [1]. It is a native of the Amazon basin of South America but has proliferated extensively globally, as seen in Figure 1. E. crassipes constitutes a threat to biodiversity, ecosystem functionality, human health, and socio-economic growth as well as poor people's livelihoods and income generation. This prompted African countries to make commitments to numerous international environmental treaties and, consequently, set up their national action plans concerning the severity of the infestations to their local environments. 


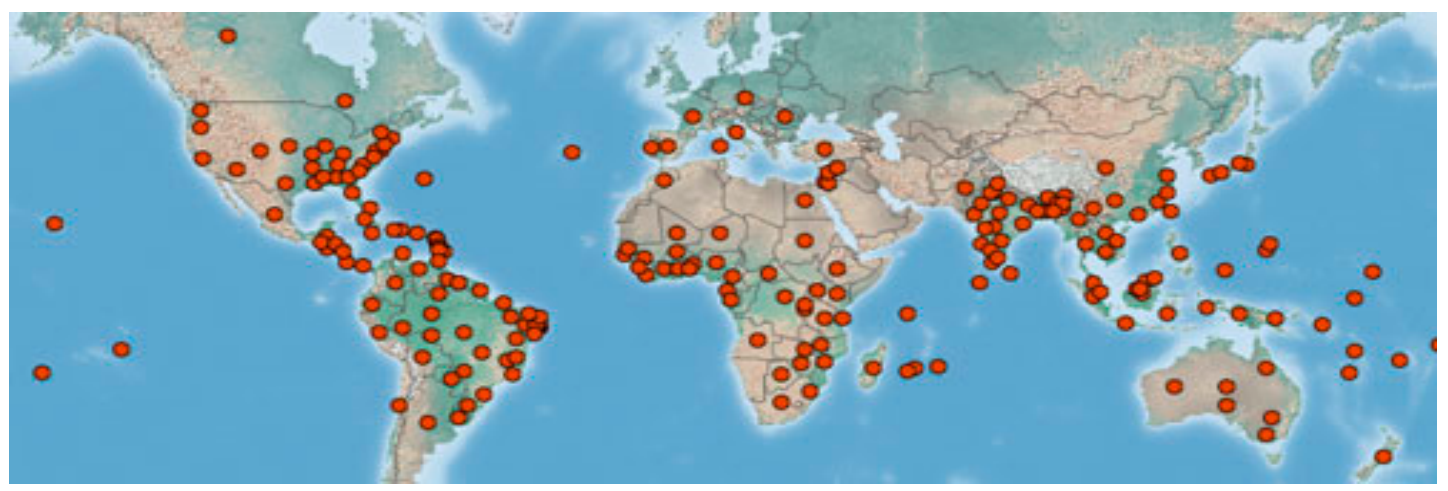

Figure 1. Global spread of water hyacinth. Data from [2].

The three most common techniques which are used for the control include chemical, mechanical, and biological [3]. Chemical control is moderately cheap but can hardly be used as a long-term solution considering its adverse effect on the environment [4]. Mechanical control, on the other hand, requires the use of machinery and has been observed to retrieve significant amounts of biomass. Despite its potential, it is very expensive due to the high cost of mechanical equipment and manpower, as well as the initial investment [4]. On the contrary, biological control is widely considered as an optimistic approach that is sustainable in controlling water hyacinths as this method has the potential to decrease the invasive plants' competitive advantages over native plants [5]. Despite its potential, it is assumed to suffer from experimental proof. For instance, the biological control programme on Lake Victoria was criticized by Williams et al. [6], who stated that the quick decrease in the weed in two years might not only be a result of the Neochetina spp. weevils. They insinuated that it could probably be due to the El Niño cloudy weather, which decreased the light intensity.

The cost of controlling these invasive plants is high and the Southern African countries are poorly equipped for this liability as the process has to be performed consistently. It is estimated that in South Africa, the cost of controlling invasive species exceeds 700 million U.S. Dollars (USD) per annum, which is approximately 0.3 percent of South Africa's gross domestic product (GDP) and might increase above 5 percent if not mitigated [7]. However, there are potential benefits of water hyacinth which can be used to make financial and environmental returns [3,8-11]. This review, therefore, is a comprehensive exploration of the valuable recovery resources from water hyacinth. It compared the techno-economic feasibility of utilising these weeds against controlling them. A key component of this review revolves around the importance to identify factors that are pivotal for the viability of mitigating the adverse effects of water hyacinth and consequently are deliberated to be critical for its implementation. The review argues that the fundamental relationship between viability and implementation of any mitigation strategy is on the hypothesis that stakeholders will be keen to adopt a technique if it offers higher profits or efficacy than the current mitigation measures.

This review was able to document that the economic feasibility of control methods which, on one hand, are used to calculate the economic value of water hyacinth, mainly relies on assumptions whose reliability and sustainability are questionable, thus implying limitations on using this kind of control methods. On the other hand, the costs and benefits of utilising water hyacinth are more quantifiable, making them susceptible to changes associated with the time value of money and sensitivity analysis of possible fluctuations in cashflows. The review, therefore, envisaged that the outcome of the observations made in this paper will contribute to contemporary policy discussions and research and development, and also influence sustainable environmental management of water hyacinth in Southern Africa.

\section{Methodological Considerations}

This paper is based on a desktop review study which was conducted between 2 and 6 July 2020 . An extensive web-based search using Google, SCOPUS, Ebscohost, and Web of Science was conducted, 
which resulted in the selection of 49 papers (see Figure 2). The meta-analysis and Collaboration for Environmental Evidence (CEE) (2013) guidelines were employed as analytical frameworks. The "All fields" option was used in identifying all the relevant literature. Keywords such as "water hyacinth", "control methods for water hyacinth", "benefits of water hyacinth", "water hyacinth utilization", and "techno-economic feasibility" were entered in these search engines. The scope of the study focused on articles published from 2005-2020 on the utilisation component, however, the search on the techno-economic feasibility was left open-ended to allow for a substantive amount of literature to be yielded. This was paramount because of the limited articles on techno-economic feasibility. All financial implications, stated in different currencies, were converted to US Dollars using the particular exchange rates from the Xe website of 7 July 2020, and converted to millions for uniformity. Although an effort was made for the review to be comprehensive, we acknowledge that the searches may have been limited based on the following assumptions:

(1) Existing literature may have been omitted by not having a linkage to the keywords,

(2) Relevant articles only in the English language were examined,

(3) Some were not available due to controlled access paywalls, and

(4) Others were not catalogued in a searchable database.

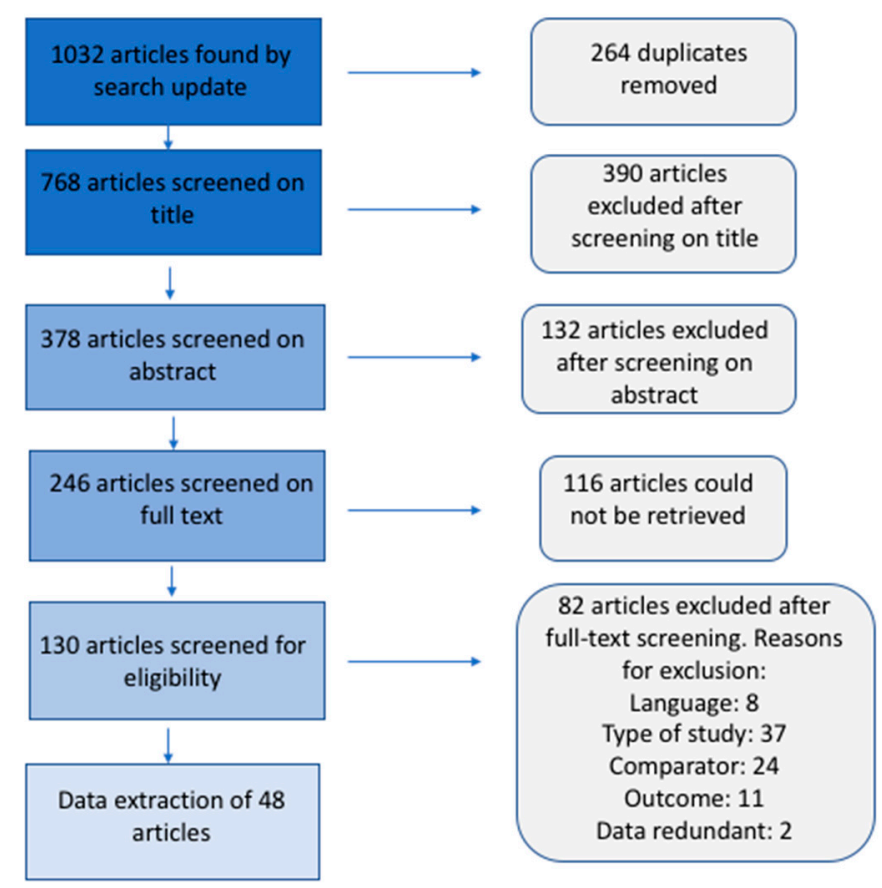

Figure 2. A flow chart representing the methodology for the review. Personal creation.

\section{Valuable Materials Recovery from Water Hyacinth}

A sum of 29 articles out of 48 retrieved was on the utilisation of water hyacinth. The majority (28\%) of the recovery methods are on bioenergy (biogas, bioethanol, and briquette), $21 \%$ of these articles used it for phytoremediation, $10 \%$ for biofertilizer, $7 \%$ for high-value chemicals (Furfurals), $7 \%$ for animal feed, $4 \%$ for insulation board in building, $10 \%$ for enzyme production, $10 \%$ for biopolymers, and $3 \%$ used a combined method (used it for phytoremediation and subsequently bioethanol), as shown in Figure 3. These valuable material recovery technologies are all based on the chemical compositions of the invasive plant. Table 1 shows the biochemical compositions of water hyacinth from different studies. It is worth noting that the environment where water hyacinth grows affects its chemical composition [12]. The summary of the reviewed articles on valuable material recovery from water hyacinth is presented in Table 2. 


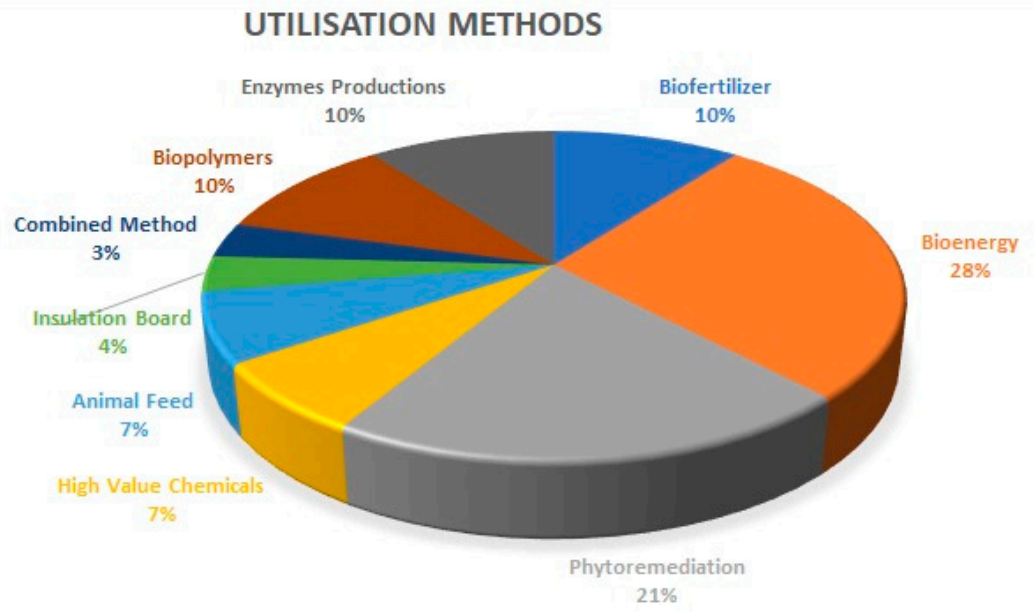

Figure 3. A representation of the beneficial use of water hyacinth. Personal creation.

Table 1. Biochemical composition of water hyacinth.

\begin{tabular}{ccccccc}
\hline \multirow{2}{*}{ Parameters (\%) } & \multicolumn{7}{c}{ References } \\
\cline { 2 - 7 } & {$[13]$} & {$[14]$} & {$[15]$} & {$[16]$} & {$[17]$} & {$[18]$} \\
\hline Hemicellulose & 33.4 & - & 30.0 & 30.0 & 20.82 & - \\
\hline Cellulose & 19.7 & - & 24.8 & 24.0 & 30.65 & - \\
\hline Lignin & 9.27 & - & 5.6 & 16.0 & 2.01 & - \\
\hline Crude protein & 20.0 & 10.01 & - & - & 5.90 & - \\
\hline Carbon & - & - & 31.5 & 38.4 & 37.80 & 14.4 \\
\hline Nitrogen & - & - & 2.80 & 2.9 & 0.90 & - \\
\hline Oxygen & - & - & 31.7 & 28.1 & - & 49.5 \\
\hline Hydrogen & - & - & 6.2 & 5.85 & 5.30 & - \\
\hline Sulphur & - & - & - & 0.47 & 0.10 & - \\
\hline Phosphorus & 0.53 & 0.28 & - & 0.77 & - & - \\
\hline Calcium & 0.58 & 3.08 & - & 1.32 & - & 4.73 \\
\hline Magnesium & 0.17 & 0.65 & - & - & - & 1.96 \\
\hline Potassium & - & 4.13 & - & 2.78 & - & 8.26 \\
\hline Sodium & - & 0.13 & - & 1.44 & - & 0.58 \\
\hline
\end{tabular}


Table 2. Summary of literature reviewed on material recovery technologies of water hyacinth.

\begin{tabular}{|c|c|c|c|c|}
\hline $\mathrm{S} / \mathrm{N}$ & Reference & Aim & Utilisation & Key Findings \\
\hline 1 & [19] & $\begin{array}{l}\text { The use of effective microorganisms-based water hyacinth } \\
\text { compost as biosorbent for removing basic dyes }\end{array}$ & Biosorbent & $\begin{array}{c}\text { The efficacy of effective microorganisms based water } \\
\text { hyacinth compost to remove basic dyes was obtained } \\
\text { as Methylene Blue (98.9\%), Malachite Green }(98.4 \%) \text {, } \\
\text { and Basic Blue41 (89.1\%). }\end{array}$ \\
\hline 2 & [20] & Use of water hyacinth as biosorbent for removal of $\mathrm{Cr}$ (III) & Biosorbent & Water hyacinth removed 76.9 mg/g of Cr (III). \\
\hline 3 & [21] & $\begin{array}{l}\text { Utilising E. crassipes petiole as an adsorbent for removing } \\
\text { toxic Congo red dye }\end{array}$ & Biosorbent & $\begin{array}{c}\text { Sodium chloride treated water hyacinth petiole } \\
(94.88 \%) \text { removed a greater percentage than untreated } \\
(94.51 \%) .\end{array}$ \\
\hline 4 & [22] & $\begin{array}{l}\text { Investigating the practice of phytoremediation of } \\
\text { agroindustry wastewater using water hyacinth }\end{array}$ & Phytoremediation & $\begin{array}{l}\text { Phytoremediation by water hyacinth can be } \\
\text { considered a viable alternative to reduce the pollution } \\
\text { caused by slaughterhouse effluents. }\end{array}$ \\
\hline 5 & [23] & $\begin{array}{l}\text { The use of citric acid cross-linked with E. crassipes root } \\
\text { powder for the bioremediation of total inorganic arsenic and } \\
\text { the turbidity from polluted water }\end{array}$ & Phytoremediation & $\begin{array}{l}\text { The cross-linking improved stability and reduced } \\
\text { turbidity. The maximum adsorption capacity of } 28 \mu \mathrm{g} \\
\text { of arsenic/g was recorded. }\end{array}$ \\
\hline 6 & [24] & $\begin{array}{l}\text { Investigating the rate of phytoremediation of nutrients and } \\
\text { organic carbon using WH at Sago mill effluent }\end{array}$ & Phytoremediation & $\begin{array}{l}\text { WH decreased the concentrations of COD } \\
(86.4-97.2 \%) \text {, ammonia }(91.4-97.3 \%) \text { and phosphorus } \\
(80.4-97.2 \%) \text { within } 30 \text { days of exposure }\end{array}$ \\
\hline 7 & [25] & $\begin{array}{l}\text { Assessing the remediating potential of E. crassipes on } \\
\text { chromium polluted water and subsequently use the } \\
\text { biomass laden with chromium to evaluate the generation } \\
\text { of bioethanol }\end{array}$ & $\begin{array}{l}\text { Phytoremediation and } \\
\text { Bioethanol }\end{array}$ & $\begin{array}{l}\text { Waste water with } 620 \mathrm{mg} / \mathrm{L} \text { concentration of chromium } \\
\text { was remediated to } 180 \mathrm{mg} / \mathrm{L} \text { by water hyacinth, while } \\
\text { the other batch of } 714 \mathrm{mg} / \mathrm{L} \text { was reduced to } 312 \mathrm{mg} / \mathrm{L} \text {. } \\
\text { Ethanol yield from the WH biomass of } 620 \mathrm{mg} / \mathrm{L} \text { was } \\
9,000 \mathrm{mg} / \mathrm{L}, 714 \mathrm{mg} / \mathrm{L} \text { was } 10,000 \mathrm{mg} / \mathrm{L}, \text { while WH } \\
\text { biomass without chromium was } 12,100 \mathrm{mg} / \mathrm{L} \text {. }\end{array}$ \\
\hline 8 & [26] & $\begin{array}{l}\text { Evaluating the consequences of substituting Tifton- } 85 \text { hay } \\
\text { with water hyacinth hay in the diets of sheep }\end{array}$ & Animal feed & $\begin{array}{l}\text { The hay from } E \text {. crassipes had } 159 \mathrm{~g} \mathrm{CP} / \mathrm{Kg} \text { DM of } \\
\text { protein compared to Tifton- } 85 \text { hay of } 63.9 \mathrm{~g} \mathrm{CP} / \mathrm{Kg} \text { DM. } \\
\text { Substituting Tifton- } 85 \text { hay with WH is cost-effective } \\
\text { and not toxic to sheep. }\end{array}$ \\
\hline 9 & [27] & $\begin{array}{l}\text { Evaluating the prospective of water hyacinth as aquafeed } \\
\text { for grass carp (Ctenopharyngodon idella). }\end{array}$ & Animal feed & $\begin{array}{l}\text { Leaf meal was more appropriate than whole plant and } \\
\text { root meal. }\end{array}$ \\
\hline 10 & [28] & Utilization of water hyacinth as mulch in turmeric & Mulch & $\begin{array}{c}\text { Turmeric growth and yield from jack leaves }(22.45 \\
\mathrm{t} / \mathrm{ha} \text { ) were considered to be at par with water hyacinth } \\
\text { (20.52 t/ha) and coconut leaves }(20.12 \mathrm{t} / \mathrm{ha}) \text { compared } \\
\text { to without mulch }(15.91 \mathrm{t} / \mathrm{ha}) \text {. }\end{array}$ \\
\hline
\end{tabular}


Table 2. Cont.

\begin{tabular}{|c|c|c|c|c|}
\hline $\mathrm{S} / \mathrm{N}$ & Reference & Aim & Utilisation & Key Findings \\
\hline 11 & [29] & $\begin{array}{l}\text { Evaluating the influence of water hyacinth drum composite } \\
\text { (WHDC) and conventional vermicompost on soil quality } \\
\text { and crop growth for tomatoes and cabbage plants }\end{array}$ & Compost & $\begin{array}{l}\text { The crop yield revealed improved soil quality. } \\
\text { Cabbage and tomatoes yield were best at WHDC + } \\
\text { inorganic fertilizer (NPK) and Vemicompost + NPK, } \\
\text { however, the plants had elevated uptake of metal } \\
\text { from WHDC. }\end{array}$ \\
\hline 12 & [30] & $\begin{array}{l}\text { Investigation on the viability of utilising water hyacinth } \\
\text { composted with pig manure and without pig manure as a } \\
\text { peat substitute }\end{array}$ & Compost & $\begin{array}{c}\text { For tomato seedling germination, substrates } 1-3 \\
\text { performed well }(92.0-95.3 \%) \text {, while Figure substrate } 4 \\
\text { was poor }(76.0 \%) \text {. However, substrate1 }(72.5 \%) \\
\text { performed better than others in cabbage growth, } \\
\text { with substrate4 being the lowest. }\end{array}$ \\
\hline 13 & [17] & $\begin{array}{l}\text { Investigating the potential of furfural production from } \\
\text { water hyacinth }\end{array}$ & Furfural & $\begin{array}{c}7.9 \text { wt. \% of furfural was produced from water } \\
\text { hyacinth, which was higher than that of rice straw } \\
\text { or hulls. }\end{array}$ \\
\hline 14 & [31] & $\begin{array}{c}\text { Converting water hyacinth to chemicals using } \mathrm{FeCl}_{3} \text { as } \\
\text { low-cost and nontoxic oxidant }\end{array}$ & High-value chemicals & $\begin{array}{l}\text { High-value products such as Hydroxymethylfurfural } \\
\text { (HMF), furfural, and aromatic compounds } \\
\text { were produced. }\end{array}$ \\
\hline 15 & [32] & $\begin{array}{l}\text { The potential use of } \mathrm{WH} \text { petiole for manufacturing thermal } \\
\text { insulation particleboard. }\end{array}$ & $\begin{array}{l}\text { Bio-based insulation board for } \\
\text { construction }\end{array}$ & $\begin{array}{l}\text { The low lignin content of WHP and the internal } \\
\text { porous structure enables the creation of } \\
\text { self-supporting binder-less WHP panels without } \\
\text { requiring a heat energy procedure. }\end{array}$ \\
\hline 16 & [33] & $\begin{array}{l}\text { Investigating the potential of producing cellulase from } \\
\text { Eichhornia crassipes by native bacteria }\end{array}$ & Enzymes & $\begin{array}{l}\text { The bacterial isolates identified as Alcaligens faecalis } \\
\text { (SMB 3), Aquaspirillum sp. (WHB3) and unidentified } \\
\text { (WHB4), produced cellulase enzyme from } \\
\text { water hyacinth. }\end{array}$ \\
\hline 17 & [34] & $\begin{array}{l}\text { Determining the effects of varied production states on the } \\
\text { yield of } \beta \text {-glucosidase and endoglucanase by Rhizopus oryzae } \\
\text { MTCC } 9642 \text { from water hyacinth }\end{array}$ & Enzymes & $\begin{array}{l}\text { Optimal endoglucanase yield of } 495 \mathrm{U} / \mathrm{mL} \text { was } \\
\text { attained at a substrate concentration of } 1.23 \%, \mathrm{pH} 7.29 \text {, } \\
\text { and temperature } 29.93^{\circ} \mathrm{C} \text { while optimal } \beta \text {-glucosidase } \\
\text { yield of } 137.32 \mathrm{U} / \mathrm{mL} \text { was attained at a substrate } \\
\text { concentration of } 1.25 \%, \mathrm{pH} 6.66 \text {, } \\
\text { and temperature } 32.09^{\circ} \mathrm{C} \text {. }\end{array}$ \\
\hline 18 & [35] & $\begin{array}{c}\text { Enhancing the production of xylanase from water hyacinth } \\
\text { using Trichoderma species }\end{array}$ & Enzymes & $\begin{array}{l}\text { The highest production of xylanase }(3170 \mathrm{U} / \mathrm{mL}) \text { from } \\
\text { water hyacinth was at concentration of } 6 \% w / v, \\
\text { agitation } 150 \mathrm{rpm} \text {, and } \mathrm{pH} 5.0 .\end{array}$ \\
\hline
\end{tabular}


Table 2. Cont.

\begin{tabular}{|c|c|c|c|c|}
\hline $\mathrm{S} / \mathrm{N}$ & Reference & Aim & Utilisation & Key Findings \\
\hline 19 & [36] & $\begin{array}{l}\text { A report on the phytochemistry and pharmacological } \\
\text { purposes of Eichhornia crassipes }\end{array}$ & Biopolymers & $\begin{array}{c}\text { Extracts from E. crassipes have pharmacological effects } \\
\text { For example, the ethyl acetate and aqueous extracts } \\
\text { have a suitable wound healing potential on an } \\
\text { incision wound. }\end{array}$ \\
\hline 20 & [37] & $\begin{array}{c}\text { The use of water hyacinth biomass for producing } \\
\text { Polyhydroxybutyrate (PHB) }\end{array}$ & Biopolymers & $\begin{array}{l}\text { WH is a cost-effective option for producing } \\
\text { sustainable biopolymer as the PHB produced was of } \\
\text { good standard }\end{array}$ \\
\hline 21 & [38] & Converting cellulose from E. crassipes into hydrogel & Biopolymers & $\begin{array}{l}\text { The hydrogel with glutaraldehide additive had the } \\
\text { highest water absorption capacity }(285 \%) \text { at } 25^{\circ} \mathrm{C} \text {, } \\
\text { while hydrogel with polyvinyl alcohol had the highest } \\
\text { maximum stress compression }(3.15 \mathrm{kPa}) .\end{array}$ \\
\hline 22 & [39] & $\begin{array}{l}\text { Evaluating the fuel features of briquettes produced from the } \\
\text { mixture of } E \text {. crassipes and empty fruit bunch }\end{array}$ & Briquette & $\begin{array}{l}\text { The combination of WH and EFB showed a high } \\
\text { prospective as the combustion properties: moisture } \\
\text { content, ash content, fixed carbon content, } \\
\text { and average calorific value are within a suitable range. }\end{array}$ \\
\hline 23 & [12] & $\begin{array}{l}\text { Evaluating the best method and the optimal conditions for } \\
\text { fermentable sugar production from water hyacinth; these } \\
\text { sugars were then fermented to bioethanol. }\end{array}$ & Bioethanol & $\begin{array}{l}14 \mathrm{~g} / \mathrm{l} \text { bioethanol produced from } \mathrm{C} \text {. tropicalis } \mathrm{Y}-26 \text { in the } \\
\text { fermentation of fungal- and acid-treated hydrolysate } \\
\text { was higher than the } 6 \mathrm{~g} / \mathrm{l} \text { bioethanol produced from } \\
\text { the fermentation of acid-only-treated hydrolysate. }\end{array}$ \\
\hline 24 & [40] & $\begin{array}{l}\text { Enhancing bioethanol yield from water hyacinth by } \\
\text { integrated pre-treatment method }\end{array}$ & Bioethanol & $\begin{array}{l}1.40 \mathrm{~g} / \mathrm{L} \text { of bioethanol produced from the pretreatment } \\
\text { of water hyacinth with microbial + dilute acid } \\
\text { pre-treatment. This was achieved without any } \\
\text { additional cellulase. }\end{array}$ \\
\hline 25 & [41] & $\begin{array}{l}\text { Enhancing biogas production from anaerobic digestion of } \\
\text { water hyacinth }\end{array}$ & Biogas & $\begin{array}{l}\text { Sun-drying increased the solid content to } 40 \% \text { and } \\
\text { subsequently increased biogas yield by } 14 \% \text {. In as } \\
\text { much as ensilation was effective for preservation, } \\
\text { the biogas yield was smaller by } 20 \% \text { as compared to } \\
\text { fresh WH. Co-digestion with food waste ( } 400 \mathrm{~mL} / \mathrm{g} \\
\text { VS) yielded more biogas as compared to WAS (150 } \\
\mathrm{mL} / \mathrm{g} \text { VS) and mono-digestion ( } 140 \mathrm{~mL} / \mathrm{g} \mathrm{VS})\end{array}$ \\
\hline
\end{tabular}


Table 2. Cont.

\begin{tabular}{|c|c|c|c|c|}
\hline $\mathrm{S} / \mathrm{N}$ & Reference & Aim & Utilisation & Key Findings \\
\hline 26 & [42] & $\begin{array}{l}\text { Enhancing the solubilization of water hyacinth for biogas } \\
\text { production using biological pre-treatment }\end{array}$ & Biogas & $\begin{array}{l}\text { SFa2 (Citrobacter werkmanii VKVVG4, MF099900) } \\
\text { pre-treated WH had the highest percentage of solubility } \\
\text { of lignin, cellulose, and hemicellulose, followed by BR2 } \\
\text { and UN3D2. BMP test on SFa2 pre-treated water } \\
\text { hyacinth yielded biogas of } 3737 \pm 21 \mathrm{~mL} \text {, whereas } \\
\text { untreated WH yielded } 3038 \pm 13 \mathrm{ml} \text {. }\end{array}$ \\
\hline 27 & [43] & $\begin{array}{l}\text { Investigation on the effects of chemical pre-treatment } \\
\left(\mathrm{H}_{2} \mathrm{SO}_{4}\right) \text { on biogas production from water hyacinth }\end{array}$ & Biogas & $\begin{array}{l}\text { Cellulose was degraded during pre-treatment. } \\
\text { The optimum biogas yield of } 424.30 \mathrm{~mL} \text { resulted from } \\
\text { the } 5 \% v / v \mathrm{H}_{2} \mathrm{SO}_{4} \text { pre-treatment at a residence time of } \\
\qquad 60 \mathrm{~min} \text {. }\end{array}$ \\
\hline 28 & [44] & $\begin{array}{l}\text { Comparative investigation on biogas yield and quality from } \\
\text { anaerobic digestion of water hyacinth and Salvinia }\end{array}$ & Biogas & $\begin{array}{l}\text { Biogas production from WH ( } 552 \mathrm{~L} / \mathrm{Kg} \text { VS) was } \\
\text { considerably greater }(p<0.05) \text { than Salvinia }(221 \mathrm{~L} / \mathrm{Kg} \\
\text { VS). The biogas yield is estimated to generate } 1.18 \\
\mathrm{kWh} \text { and } 0.47 \mathrm{kWh} \text { energy from water hyacinth and } \\
\text { Salvinia (per kg VS), respectively. }\end{array}$ \\
\hline 29 & [45] & $\begin{array}{l}\text { The potential bioenergy recovery from anaerobic digestion } \\
\text { of water hyacinth and its co-digestion with fruit and } \\
\text { vegetable waste }\end{array}$ & Biogas & $\begin{array}{c}\text { The biogas potential of WH-FVW }\left(0.141 \mathrm{~m}^{3} / \mathrm{kg} \text { VS }\right) \\
\text { co-digestion was } 23 \% \text { higher than that of WH alone } \\
\left(0.114 \mathrm{~m}^{3} / \mathrm{kg} \text { VS). }\right.\end{array}$ \\
\hline
\end{tabular}




\subsection{Phytoremediation}

Water hyacinth has the ability to adsorbing pollutants due to its polyfunctional meta-binding sites and chemical functional groups. In the use of water hyacinth for the adsorption of dye, most studies investigated the effects on cationic dyes [19,20] with limited studies on anionic dyes [21]. Other studies have also confirmed its use to remediate heavy metals [22-24]. Nash et al. [24] assessed the effectiveness of WH in remediating Sago Mill Effluent (SME) at 20\%, 15\%, and 10\% concentration each for 30 days. The result showed reduced concentration of phosphorus, ammonia, and chemical oxygen demand (COD) at $80.4-97.2 \%, 91.4-97.3 \%$, and $86.4-97.2 \%$ respectively. There have been considerable disagreements on the degree of adsorption of heavy metal by E. crassipes because the interaction of multiple metals is yet to be quantified; it is assumed that water hyacinth contains lignocellulose that can result in tethering of metal ions. The utilisation of water hyacinth as a biological agent for phytoremediation has been criticised because there are possibilities of the plant evading the selected site and becoming a nuisance. Moreover, some studies failed to state what happens to the water hyacinth biomass after phytoremediation as the heavy metals remain stuck to the weed. Sayago [25] designed a sustainability system whereby water hyacinth used to remediate chromium-infested water was subsequently utilised for bioethanol production. Adequate measures are to be taken when using water hyacinth for phytoremediation considering it could adversely change the ecosystems.

\subsection{Animal Feed}

The need for food security without exerting pressure on the global land use for agricultural purposes has necessitated the search for cost-efficient, accessible, and healthy supplements. Researchers have promoted the use of water hyacinth as animal feed as it has high water and mineral content, which suggests that the nutritional value may be appropriate for certain animals. Nevertheless, with the mixture of carbohydrate additives such as molasses and rice bran, the nutritional content can be fortified. Mahmood et al. [27] assessed the potential of water hyacinth as food on the development and digestibility of grass carp (Ctenopharyngodon idella) fingerlings. Three diets were prepared with water hyacinth for feeding grass carp juveniles, namely, whole plant meal (WP), leaf meal (LM), and roots meal (RM). While LM had the highest weight gain $(7.14 \mathrm{~g})$ and digestibility of protein $(72.5 \pm 1.6 \%)$, WP had $6.87 \mathrm{~g}$ and $64.13 \pm 0.2 \%$, and RM had the lowest at $2.10 \mathrm{~g}$ and $45.54 \pm 4.8 \%$ respectively. Protein digestibility is a significant factor to evaluate the dietary quality of a food; high digestibility rate signifies high nutrients use. However, histology assessment revealed that the kidneys of the fish had degeneration of renal tubules, necrotic damage in tubular epithelial cells, and tubular lysis. There was no report of toxicity in the study of [26], which was aimed at substituting Tifton-85 hay used in sheep diet with water hyacinth as the globulin concentrations were suitable. It is evident that $E$. crassipes is used as animal feed, however, it calls for suitable precautious procedures such as pre-treatment before use to reduce its toxicity and seed viability.

\subsection{Bio-Fertiliser}

The use of bio-fertilisers for agriculture has sustainable benefits compared to chemical fertilisers as they increase the quality of the soil and concurrently decrease the build-up of nitrate in the soil. Eichhornia crassipes contains high nitrogen, phosphorus, and potassium elements which makes it appropriate for use as mulch [28], compost [29], or vermicomposting [46]. It has been established that water hyacinth compost is viable to replace peats, and consequently reduce the quick exhaustion of peatlands [30]. However, there is a hypothesis that using water hyacinth as a biofertilizer may result in plants having an accrual of heavy metals and this consequently occurring in human tissues. In the study of Goswami et al. [29], randomised blocks with five types of treatments (farmyard manure (FYM), inorganic fertiliser (NPK), FYM + NPK, vermicompost (VC) + NPK and water hyacinth drum compost $($ WHDC $+\mathrm{NPK})$ were used to evaluate soil quality and crop growth for tomatoes and cabbage. Cabbage and tomatoes yield were best with WHDC + NPK and VC + NPK, however, the plants had a high 
build-up of metal from the water hyacinth drum compost. The presence of earthworm (Eisenia fetida) in vermicompost causes a significant decrease in the metal concentration because earthworm has several enzymes and gut microbes that contribute to biotransformation and absorption of metals in such a way that they are protected in the organism's tissues instead of returning them into the biofertiliser as worm casts. Moreover, a leachability test by Singh and Kalamdhad [46] established that vermicomposting is not dangerous to the soil, plants, or man's wellbeing.

\subsection{High-Value Chemicals}

Chemical and thermal pre-treatment on lignocellulosic biomass result in materials such as furfurals and hydroxymethylfurfural (HMF) which until recently were seen as inhibitors. Furfural is a promising biorefinery product that will supersede fossil oil derivatives and also serve as raw material for biofuel blends [17]. In a study aimed at examining the suitability of water hyacinth in producing furfural, a yield of $7.9 \%$ was reported which was stated to be equivalent to that of other agricultural residue feedstocks. However, one major drawback of the large-scale use of these chemicals is the inadequate cost-effective production process. A simple and cost-efficient method to produce furfural and HMF from water hyacinth by the use of non-hazardous oxidant $\left(\mathrm{FeCl}_{3}\right)$ was deployed by Liu et al. [31]. However, more studies are to be made in optimising this process.

\subsection{Insulation Boards}

The awareness of global warming and efforts in reducing energy use during construction has inspired the search for bio-based building materials. The use of water hyacinth in developing thermal insulation particle board as investigated by Salas-Ruiz et al. [32] has shown the viable performance of the aquatic plant in the construction sector. The study exposed the microstructure and chemical composition of the aquatic weed which the authors consider will boost its application as a bio-based building material.

\subsection{Enzyme Production}

Enzymes are nature's catalyst, and they control virtually all biochemical processes in the system. There is a projection of an annual growth of $6.4 \%$ for the industrial enzymes market from 2020 to 2027, and the increasing product need is expected from industries [47]. The production of enzymes involves a high cost because of the carbon source. Consequently, studies on developing alternative methods to minimise such costs are carried out as its use in the industries are affected. Water hyacinth has been utilised as a carbon source to create enzymes such as cellulase [33,34] and xylanase [35]. The high lignocellulosic content of water hyacinth biomass is suitable as a growth medium for enzyme production. These enzymes are sustainable substitutes to conservative technique as their use ensures a cost-efficient and energy efficient process, reduced waste generation, and high-value products. Enzymes have gained attention because of their wide range of applications in the pharmaceutical, food and beverage, detergents, textile, and pulp and paper industries. For example, in the food industry, cellulase and xylanase are recognised as enzymes that disrupt the structural cell walls of plants and improve extraction of fruit juices by increasing yield, reducing viscosity, and enhancing cloud stability.

\subsection{Biopolymers}

The use of synthetic materials from polyesters is currently criticized because they are not sustainable and create a lot of ecological harms; however, biopolymers, which are innately occurring resources, are highly compatible, environmentally friendly, readily available, and cost-effective. They include polysaccharides, polypeptides, and polynucleotides. These biopolymers have been extensively used for various purposes such as food packaging, hydrogels, drug delivery, and pharmaceuticals. Presently, studies are exploring numerous renewable materials for biopolymer production. Water hyacinth is the subject of attention because of its cellulosic content and proliferation rate. Cellulose from water hyacinth 
has been used to make polyhydroxybutyrate (PHB), a resource for bioplastics. Nanomaterials fabricated from water hyacinth have been applied in wound dressings [36], biodegradable packaging films [37,48], control release technology (hydrogel) [38]. However, there is a need for further investigation on the wound healing attributes of the aquatic weed.

\subsection{Bioenergy}

The awareness of global warming has called for energy security, a decrease in greenhouse gas emissions, and a healthy environment. This call has led to a significant shift from fossil fuels to renewable energy sources such as biomass. Water hyacinth does not compete with land resources or food security; it grows rapidly, is highly available, and is biodegradable, which makes it suitable as biomass for producing bioenergy. However, its major drawback is the $95 \%$ water content which consequently raises the cost of bioenergy production [8]. E. crassipes has been utilised in the production of briquettes, bioethanol, and biogas.

\subsubsection{Briquettes}

Briquettes are densified agricultural products such as sawdust, palm kernels, and husks from cowpeas, rice. They are alternatives to fuelwoods, charcoal, and paraffin, as they are known for their high calorific value, expediency, requires little storing capacity, and they do not release smoke. Eichhornia crassipes can be utilised in the production of briquettes; although its calorific value is lower than coal, it could be co-fired to reduce the greenhouse gases released by coal-fired power plants. The use of binders is recommended for optimal burning time; however, such binders should be sustainable and cost-effective. The result of the investigation on the use of water hyacinth and empty fruit brunch fibers (25:75) as briquettes indicated $17.17 \mathrm{MJ} / \mathrm{kg}$ calorific rate and 3.73\% low ash content [39].

\subsubsection{Bioethanol}

Bioethanol is made from the fermentation of biomass and is a promising alcoholic biofuel existing in the market today because of its clean combustion. The structural features of monosaccharide and polysaccharide in E. crassipes make it viable for bioethanol production. Its polymeric carbohydrate is predominantly cellulose and hemicellulose. While the cellulose contains glucose monomers, hemicellulose contains various polymers such as xylose, arabinose, galactose, and mannose [40,49]. Amongst the different stages in the breakdown of lignocellulose to fermentable sugars, the saccharification stage is considered a limiting stage [12]; however, the emergence of economical bioprocess technology has brought hope to the industry. Furthermore, the high cost of an enzyme such as cellulase is seen as a major hurdle for the optimisation and affordability of bio-ethanol. Nevertheless, some studies have reported high bioethanol yield in the absence of cellulase [12,40]. While Madian et al. [12] explored the use of Candida tropicalis Y-26 in producing bioethanol from water hyacinth hydrolysate, Zhang et al. [40] involved the use of Phanerochaete chrysosporium, Phanerochaete chrysosporium combined with dilute acid, and Phanerochaete chrysosporium combined with dilute alkaline. Both studies revealed the highest bioethanol production from the fermentation of both acid- and fungal-treated hydrolysate.

\subsubsection{Biogas}

Biogas is a valued source of energy expedient for the production of heat, electricity, and fuel for transportation. Apart from biogas, digestate is also obtained from anaerobic digestion and is used as biofertilizer. Much research has shown an extensive disparity in biogas yield from anaerobic degradation of water hyacinth under different investigational situations $[43,44,50]$. This is because the technology is reliant on the activities of the microbial consortium, which consecutively depends on several parameters. Efforts have been made in increasing the biogas yield by pre-treatment [42], optimising the process parameters, appropriate digester design, stimulating the microbial communities, and co-digestion [41,45]. 


\section{Techno-Economic Analysis of Water Hyacinth Mitigation}

Economic assessment plays a vital part in evaluating the reasonable accomplishment of IAS control projects required to support continual sponsorship of such programs. This is particularly imperative considering that other social development projects are competing for inadequate resources [51]. The cost of mitigating invasive species in Southern Africa's region is not available at the time of this review. However, the South African government has expended above 100 million USD on invasive species control between 1995 and 2000 [52]. They explained that the major distinctive aspect of IAS control programmes has been the capability to influence additional benefits (by engaging the unemployed people for labour-intensive control methods or subsidizing herbicides to farmers) for the costly mitigation programmes from the government's poverty alleviation financial plan. Nevertheless, the costs were not sustainable in the long run considering the proliferation rate of these invasive species. Introducing biological control reduced the cost incurred by the government. South Africa, which is the spearhead in the biocontrol of invasive species, has invested a sum of 6.8 million USD in research and development of biocontrol of IAPs from 2014-2017 [53].

A total number of sixteen empirical studies collectively aimed at uncovering the cost-benefit analysis of deploying various control and utilisation methods in dealing with water hyacinth were compared. The biological method of control is the most commonly used $[5,54,55]$ while the chemical [5,56], integrated [5,57], and mechanical [56] are other controlling methods used. These studies used different models for their analysis, and the choice of these models was based majorly on assumptions such as prevailing market prices, opportunity costs of fishermen, farmers, and traders' lost revenues [55], prevented volume of water that would have been lost due to evapotranspiration [5,51,54], potential revenue in tourism and real estate markets [5,57]. Cost-benefit analysis (CBA) and producer price index (PPI) were the most common appraisal methods, as seen in Table 3. Arp et al. [51] adopted the Residual Value Method, while the authors of [56] did not adopt any known project appraisal methods. Although the studies unanimously concluded that the benefits of control methods outweighed their costs, reliability of the premised assumptions, neglect of time, value of money, and quantification of extrinsic benefits are major shortcomings of assessing economic visibility of the control method. The limitations of water hyacinth control include unreliable and unsustainable assumptions, no standard evapotranspiration rate for analysis, and failing to consider some other factors that may affect the economic viability, such as the adverse effects of the mitigation measures on biodiversity or damage to infrastructures equally.

The utilisation of water hyacinth aims at using a beneficial means of managing the menace of E. crassipes infestation and at the same time meeting the needs of humans. Seven studies investigated the economic feasibility of the water hyacinth utilization, as seen in Table 4. Since both costs and revenues of utilisation methods are intrinsic (unlike the control methods), the economic feasibility models used were more realistic and adaptive to possible fluctuations in future cashflows and discount rates. The net present value (NPV), which primarily recognises the time value of money using the prevailing discount rate and supports sensitivity of changes in future cash flow and discount rates, was mostly used [58-61] Profit margin, Return on Assets (ROA), and payback periods, Internal Rate of Return (IRR), and Life Cycle Analysis (LCA), which do not factor in the time value of money, were also used [61-64]. Due to the quantifiability and traceability of costs and revenues from the utilisation methods, many of the studies were able to use more than one feasibility model as a way of compensating for the shortcomings of each of the models $[58,60,61,63,64]$. 
Table 3. Economic feasibility of water hyacinths using control methods.

\begin{tabular}{|c|c|c|c|c|c|c|c|c|c|c|}
\hline $\mathrm{S} / \mathrm{N}$ & Reference & Country & $\begin{array}{l}\text { Control } \\
\text { Method }\end{array}$ & Lifespan & Model & Benefit (\$) & Cost (\$) & $\begin{array}{l}\text { Cost-Benefit } \\
\text { Ratio }\end{array}$ & $\begin{array}{l}\text { Discount } \\
\text { Rate (\%) }\end{array}$ & Key Findings \\
\hline 1 & \multirow{3}{*}{ [5] } & South Africa & Chemical & 24 & PPI & - & 0.25 million & - & - & \multirow{3}{*}{$\begin{array}{l}\text { Integrated control of water hyacinth was the most economically feasible method in relation to } \\
\text { monetary investment per hectare cleared (16 USD/ha), followed by biological ( } 18 \text { USD/ha) and then } \\
\text { chemical ( } 86 \text { USD/ha). However, the cost of mitigating the invasive plants with any of the control } \\
\text { measures is more cost-effective than not controlling it. }\end{array}$} \\
\hline 2 & & South Africa & Biological & 12 & PPI & - & 0.01 million & - & - & \\
\hline 3 & & South Africa & Integrated & 15 & PPI & - & 0.02 million & - & - & \\
\hline 4 & [51] & South Africa & - & - & RVM & 3.2 million-69 million & 0.09 million & - & - & $\begin{array}{l}\text { There is a need for invasive plant control, mostly in economically valuable water bodies. The authors } \\
\text { reported a yearly profit between } 3.2 \text { million- } 69 \mathrm{million} \text { USD for an irrigation water production worth } \\
\text { of } 2.3 \mathrm{USD} / \mathrm{m}^{3}\end{array}$ \\
\hline 5 & [54] & South Africa & Biological & 23 & СВA & 0.02 million- 0.22 million & 0.02 million & - & 5 & $\begin{array}{l}\text { Biological control significantly reduced the Dam's annual water loss. Biocontrol was cost-efficient at } \\
\text { high evapotranspiration than low evapotranspiration however, the cost of water used for the study } \\
\text { was not a marginal value, this would have increased the benefit ratio at low transpiration }\end{array}$ \\
\hline 6 & [55] & Benin & Biological & 20 & СBA & 30.5 million & 2.09 million & 124:1 & - & $\begin{array}{l}\text { The invasion of water hyacinth decreased the annual income of villagers. With a total cost of the } \\
\text { biocontrol program at } 2.09 \text { million USD, their income increased to } 30.5 \text { million USD annually. On the } \\
\text { assumption that the benefits will remain the same for the next } 20 \text { years, a present value of } 260 \text { million } \\
\text { USD was estimated. }\end{array}$ \\
\hline 7 & \multirow{2}{*}{ [56] } & Brazil & Chemical & - & - & - & 0.001 million & - & - & \multirow{2}{*}{$\begin{array}{l}\text { The cost of mechanical control was } 20 \text { times higher than the chemical control, making chemical control } \\
\text { cost-effective. }\end{array}$} \\
\hline 8 & & Brazil & Mechanical & - & - & - & 0.01 million & - & - & \\
\hline 9 & [57] & us & Integrated & 38 & СВА & 4.2 billion & 124 million & $34: 1$ & - & $\begin{array}{l}\text { For the } 38 \text {-year lifespan, the benefit for the ecosystem services was approximately } 4.2 \text { billion USD } \\
\text { while the cost of controlling the weed using both biological and chemical is } 124 \text { million USD. This } \\
\text { means that the benefit of controlling water hyacinth is beyond the cost of the control. }\end{array}$ \\
\hline
\end{tabular}

Table 4. Economic feasibility of valuable material recovery from water hyacinths.

\begin{tabular}{|c|c|c|c|c|c|c|c|c|c|c|}
\hline $\mathrm{S} / \mathrm{N}$ & Reference & Country & Utilization & $\begin{array}{c}\text { Total } \\
\text { Lifespan }\end{array}$ & Model & Benefit (\$) & Cost (\$) & $\begin{array}{c}\text { Benefits:Cost } \\
\text { Ratio }\end{array}$ & $\begin{array}{l}\text { Discount } \\
\text { Rate (\%) }\end{array}$ & Key Findings \\
\hline 1 & [58] & China & Biogas & 15 & NPV, SA & 1.9 million & 0.2 million & - & 6 & $\begin{array}{l}\text { The study evaluated an alternative of } \\
\text { producing biogas from water hyacinth, } \\
\text { instead of dumping in landfills, and the } \\
\text { outcome showed that the choice of biogas } \\
\text { is cost-effective with a positive energy } \\
\text { balance. The utilisation of water hyacinth } \\
\text { for biogas production improves water } \\
\text { quality and reduces greenhouse } \\
\text { gas emissions. }\end{array}$ \\
\hline 2 & [59] & Vietnam & Biogas & 15 & NPV & 0.001 million & 0.0004 million & - & 3.5 & $\begin{array}{l}\text { Investigation of the cost-benefit of } \\
\text { co-digestion of water hyacinth and rice } \\
\text { straw as feedstocks for the production of } \\
\text { biogas. The study considered both private } \\
\text { and social welfare benefits, and concluded } \\
\text { that the technology is cost-efficient }\end{array}$ \\
\hline
\end{tabular}


Table 4. Cont.

\begin{tabular}{|c|c|c|c|c|c|c|c|c|c|c|}
\hline $\mathrm{S} / \mathrm{N}$ & Reference & Country & Utilization & $\begin{array}{c}\text { Total } \\
\text { Lifespan }\end{array}$ & Model & Benefit (\$) & Cost (\$) & $\begin{array}{c}\text { Benefits:Cost } \\
\text { Ratio }\end{array}$ & $\begin{array}{l}\text { Discount } \\
\text { Rate (\%) }\end{array}$ & Key Findings \\
\hline 3 & [60] & China & Bioethanol & 15 & $\mathrm{NPV}, \mathrm{SA}$ & 160 million & 27.6 million & - & 10 & $\begin{array}{l}\text { The study analysed the economic } \\
\text { feasibility of producing bioethanol from } \\
\text { water hyacinth and compared it with the } \\
\text { current status of disposing in landfills. } \\
\text { The outcome showed that bioethanol } \\
\text { production from water hyacinth is } \\
\text { cost-effective and that environmental } \\
\text { benefits play an essential part in the } \\
\text { economic analysis. }\end{array}$ \\
\hline 4 & [61] & Thailand & Biogas & 20 & $\begin{array}{l}\text { NPV, IRR, BCR, } \\
\text { and PB }\end{array}$ & $\begin{array}{c}\text { Case 1: NPV }=4071.51, \\
\text { IRR }=5.02 \%, \mathrm{~PB}=12 \text { years, } \\
5 \text { months, } 12 \text { days } \\
\text { Case 2: NPV }=24,108.68, \\
\text { IRR }=\mathrm{X}, \mathrm{PB}=<1 \text { year. } \\
\text { Case } 3: \mathrm{NPV}=-68,458.17, \\
\text { IRR }=-13 \%, \\
\mathrm{~PB}=>20 \text { years }\end{array}$ & - & $\begin{array}{l}\text { Case 1 }=1.02 \\
\text { Case 2 }=1.12 \\
\text { Case 3 }=0.71\end{array}$ & - & $\begin{array}{l}\text { Case } 1 \text { (investor's money) and case } 2 \\
\text { (government-supported) imply that } \\
\text { anaerobic digestion of water hyacinth } \\
\text { using continuous stirred tank reactor } \\
\text { (CSTR) for the production of biogas is } \\
\text { more cost-effective than case } 3 \text { (Investor } \\
\text { borrowed money), which has a negative } \\
\text { NPV and cannot pay back within } 20 \text { years. }\end{array}$ \\
\hline 5 & [62] & Mexico & Biogas & 15 & LCA, SA & - & 64 million & - & 5 & $\begin{array}{l}\text { The study assessed the feasibility of a } \\
\text { constructed wetland and activated sludge } \\
\text { plant as a wastewater treatment plant and } \\
\text { the anaerobic digestion of water hyacinth } \\
\text { for biogas production. The result showed } \\
\text { that the biogas technology from CW is } \\
\text { feasible as it addresses water pollution, } \\
\text { develops renewable energy, and reduces } \\
\text { greenhouse gas emissions }\end{array}$ \\
\hline 6 & [63] & US & Bioethanol & - & LCA, SA & 0.00004 million & - & - & - & $\begin{array}{l}\text { Water hyacinth is a competitive feedstock. } \\
\text { The cost of collecting water hyacinth for a } \\
\text { biorefinery will not be more than the cost } \\
\text { of controlling it. }\end{array}$ \\
\hline 7 & [64] & Brazil & $\begin{array}{l}\text { Bio-oil and } \\
\text { Charcoal }\end{array}$ & 10 & $\begin{array}{l}\text { Profit margin, } \\
\text { ROA, and PB }\end{array}$ & - & - & $\begin{array}{c}\mathrm{PM}=62.1 \% ; \mathrm{ROA} \\
=37.4 \%, \mathrm{~PB}=4.1 \\
\text { YRS }\end{array}$ & 13 & $\begin{array}{l}\text { The investment has a profit margin of } \\
62.1 \% \text {, ROA of } 37.4 \% \text {, and PB of } 4.1 \text { years. } \\
\text { The outcome of the financial evaluation } \\
\text { implies exceptional economic desirability. } \\
\text { The use of water hyacinth for bio-oil is } \\
\text { more sustainable than sugarcane residues }\end{array}$ \\
\hline
\end{tabular}


The potential benefits of utilising water hyacinth are not an avenue for the active spread of the invasive plant; rather, it is a mechanism of reducing the detrimental impacts and costs of controlling it. Between controlling and utilisation of water hyacinth, there is no significant change in incurable costs since both methods share similarities in methods of clearance. However, the benefits associated with the two vary. While the benefits from the control methods are majorly extrinsic in nature, benefits from the utilisation methods are intrinsic and are easily ascertainable, lending them to the application of mathematical and financial models for both profitability, sensitivity, and environmental impact analyses. Among the various utilisation alternatives, biogas remained the most commonly used option $[58,59,61,62]$. The choice of biogas is empirically justifiable; not only is it a sustainable option for water hyacinth mitigation, but it also helps in diversifying the energy mix, reducing greenhouse gas emissions, and improved water quality [58] (Figure 4).

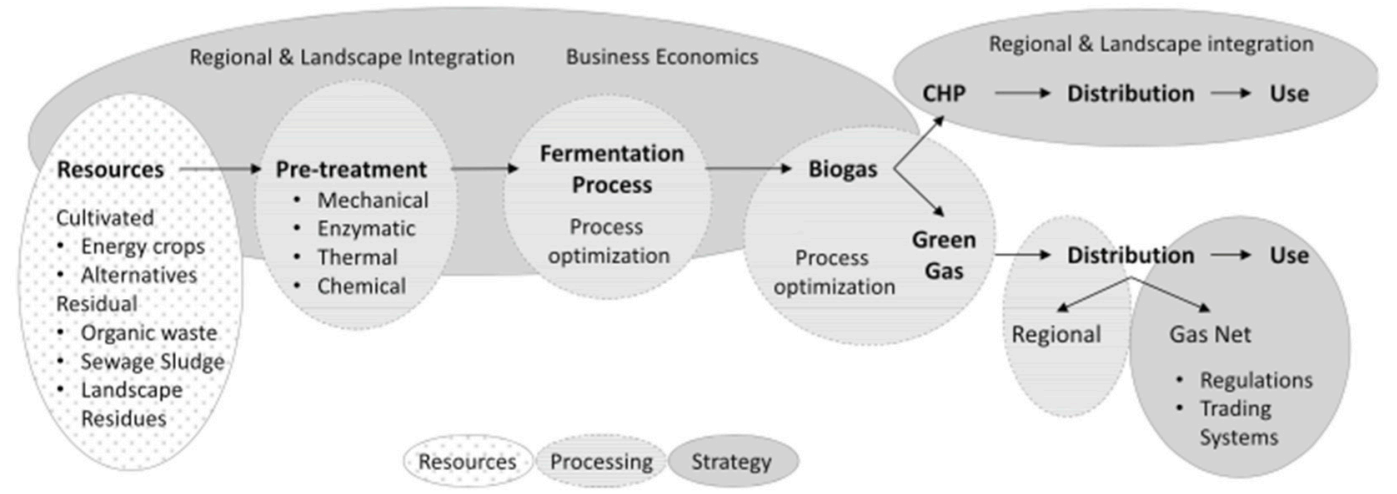

Figure 4. A representation of the biogas supply chain. Data from [65].

\section{Exploring the Water Hyacinth Benefits: An Opportunity for Southern Africa}

Speedy economic and population growth are predicted to have intense consequences on the energy-water-food nexus by 2050; while the need for water and food is to rise by 50 percent, that of energy will be almost doubled, thereby creating competition for inadequate resources [66]. Energy is fundamental to better social and economic security, and is an important aspect of poverty alleviation and refining human well-being. The current electricity need in the Southern African region, as shown in Figure 5, is 450 terawatt-hours (TWh), and the demand is expected to rise to 920 TWh in 2050 [67]. A good approach to meeting the Sustainable Development Goals' targets is to integrate the planning of these sectors. However, the present status of the energy sector market is represented by old infrastructure, increasing energy prices, unreliable electricity supply, high emissions of greenhouse gas (GHG), and vulnerability to a changing climate. Therefore, this is an opportunity for Southern Africa Development Community's (SADC) policymakers and energy traders to be driven towards the valuable resource recovery technologies from water hyacinth, considering that it can be used for animal feed, wastewater treatment, and bioenergy.

Biogas technology can be a feasible energy generation alternative for developing countries if managed and promoted appropriately [68]. It presently offers the utmost prospects to Southern Africa as it can be used for heating, fuel, and electricity and the digestate can serve as bio-fertilizer. The relatively high upfront cost of investment (designing and installing anaerobic digesters) is a major bottleneck for the realisation of bioenergy technology, however, the environmental support provided by the technology is frequently overlooked during financial evaluation. For instance, most of the fiscal evaluation of the utilisation of water hyacinth for bioenergy, of which biogas is a prime component, fails to integrate water treatment ecosystem services or biofertilizer by-product of the technology. The efficient operation of the biogas plant requires reliable feedstock that will be available for the project's lifespan and the feedstocks should be garnered within a certain radius to reduce transportation and handling cost. Utilising water hyacinth by cost-efficient, uncomplicated, and labour-intensive 
techniques is a suitable way of mitigating its proliferation and reducing the cost of control treatments. Kriticos and Brunel [69] reported the potential of E. crassipes to generate $10 \mathrm{MW} /$ year of electricity in Malawi, of which the majority of the population lack electricity access, and the 6 percent of people with access experience persistent disruptions. The technology has the potential of producing $2.5 \mathrm{GW}$ of energy, with a market prospect of 586 million USD and creating thousands of jobs in South Africa [70].

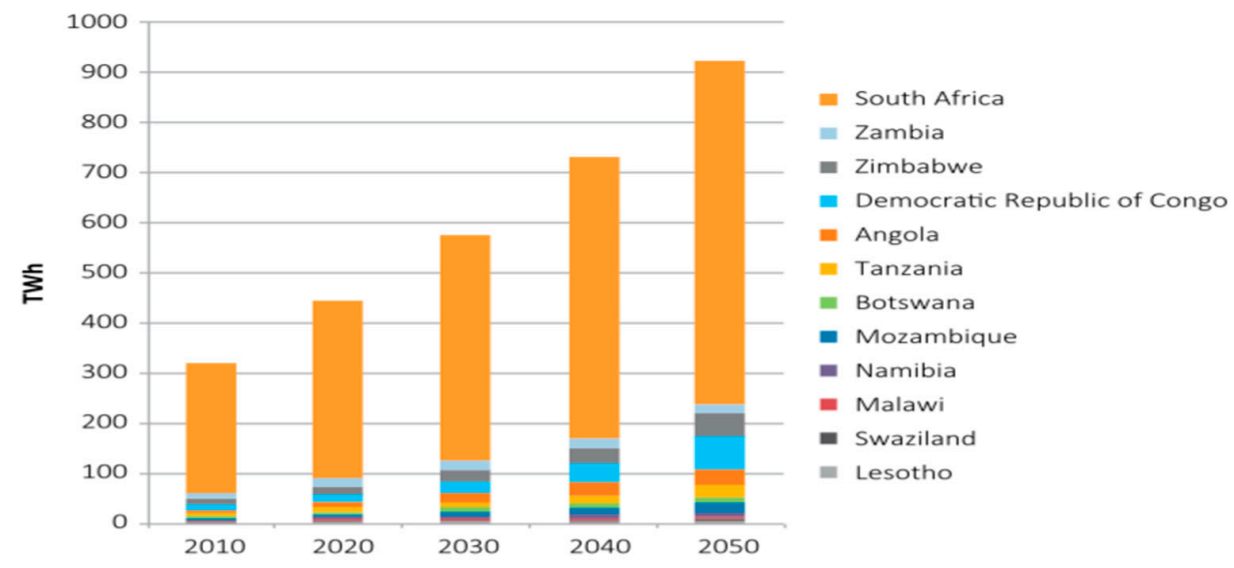

Figure 5. Predictions of electricity needs for the Southern Africa Development Community (SADC). Data from [67].

The deployment of biogas technology to Southern Africa will assist the region in achieving the SDGs. It is, therefore, essential to strengthen the existing regulations and capacity to support institutions such as the Southern African Power Pool (SAPP). SAPP is a regional cooperation formed in 1995 by SADC, which is aimed at cutting costs and forming an economical and environmentally sustainable energy market in the region. Diversification of energy portfolios can be achieved by research and development, setting up of policies such as feed-in tariffs (FITs) and institutional frameworks that will support the growth and investment of biogas, reducing the licensing fees by regulators and making the application procedure simple.

\section{Conclusions}

The high proliferation rate of water hyacinth and the high cost involved in its eradication make the existing control techniques insufficient to contain its antagonistic propagation, therefore driving empirical investigations for alternative mitigation techniques that involve exploiting the untapped potentials of the aquatic weed. The review of beneficial use of water hyacinth examined studies that explored phytoremediation, animal feed, biofertilizer, bioenergy (biogas, bioethanol, and briquettes), carbon source for enzyme production, and biopolymers as alternative but beneficial mitigation techniques. The review discovered that unlike the control methods that have uncertainties probably due to insufficient data, more sustainable, reliable, and forecastable economic feasibility models are used in utilisation methods. This review, therefore, relies on the practicability, sustainability, and economic feasibility of the utilisation method to conclude that utilisation methods are a more stably viable method of mitigating water hyacinths than the other control methods. More so, bearing in mind the growing energy, water, and food demand in Southern Africa, and the effects of climate change, there is a need to reduce the nexus pressure by building circular economies in the region which utilise wholly the unexploited potential of this plant. The use of water hyacinth as feedstock for biogas production offers valuable opportunities for diversification of energy supply and, at the same time, produces digestate that is a fertiliser. The critical hurdles in the adoption of biogas technology, as the review reveals, are the cost of investment and several bureaucratic obstacles. However, putting together suitable policy and institutional agendas, insurances and credits will impact the adoption of the technology positively. 
Author Contributions: Writing—original draft preparation, O.P.I.; methodology, O.P.I.; writing—review and editing, S.L.N., N.M.M., N.G.P., and M.D.S.; supervision, S.L.N. and N.M.M. All authors have read and agreed to the published version of the manuscript.

Funding: This research received no external funding.

Conflicts of Interest: The authors declare no conflict of interest.

\section{References}

1. Téllez, T.R.; de Rodrigo, E.M.L.; Granado, G.L.; Pérez, E.A.; López, R.M.; Guzmán, J.M.S. The water hyacinth, Eichhornia crassipes: An invasive plant in the Guadiana River Basin (Spain). Aquat. Invasions 2008, 3, 42-53. [CrossRef]

2. Centre for Agriculture and Bioscience International. Eichhornia crassipes (Water Hyacinth). Invasive Species Compendium. CAB International: Wallingford, UK, 2019; Available online: https://www.cabi.org/isc/ datasheet/20544\#toDistributionMaps (accessed on 28 February 2020).

3. Su, W.; Sun, Q.; Xia, M.; Wen, Z.; Yao, Z. The Resource utilization of water hyacinth (Eichhornia crassipes [Mart.] Solms) and its challenges. Resources 2018, 7, 46. [CrossRef]

4. Villamagna, A.M.; Murphy, B.R. Ecological and socio-economic impacts of invasive water hyacinth (Eichhornia crassipes): A review. Freshw. Biol. 2010, 55, 282-298. [CrossRef]

5. Van Wyk, E.; van Wilgen, B.W. The cost of water hyacinth control in South Africa: A case study of three options. Afr. J. Aquat. Sci. 2002, 27, 141-149. [CrossRef]

6. Williams, A.E.; Duthie, H.C.; Hecky, R.E. Water hyacinth in Lake Victoria: Why did it vanish so quickly and will it return? Aquat. Bot. 2005, 81, 300-314. [CrossRef]

7. Van Wilgen, B.W.; de Lange, W.J. The costs and benefits of biological control of invasive alien plants in South Africa. Afr. Entomol. 2011, 19, 504-514. [CrossRef]

8. Yan, S.H.; Song, W.; Guo, J.Y. Advances in management and utilization of invasive water hyacinth (Eichhornia crassipes) in aquatic ecosystems-A review. Crit. Rev. Biotechnol. 2017, 37, 218-228. [CrossRef]

9. Guna, V.; Ilangovan, M.; Anantha Prasad, M.G.; Reddy, N. Water hyacinth: A unique source for sustainable materials and products. ACS Sustain. Chem. Eng. 2017, 5, 4478-4490. [CrossRef]

10. Mitan, N.M.M. Water hyacinth: Potential and threat. Mater. Today Proc. 2019, 19, 1408-1412. [CrossRef]

11. Patel, S. Threats, management and envisaged utilizations of aquatic weed Eichhornia crassipes: An overview. Rev. Environ. Sci. Biotechnol. 2012, 11, 249-259. [CrossRef]

12. Madian, H.R.; Sidkey, N.M.; Elsoud, M.M.A.; Hamouda, H.I.; Elazzazy, A.M. Bioethanol production from water hyacinth hydrolysate by Candida tropicalis Y-26. Arab. J. Sci. Eng. 2019, 44, 33-41. [CrossRef]

13. Abdelhamid, A.M.; Gabr, A.A. Evaluation of water hyacinth as a feed for ruminants. Arch. Tierernaehr. 1991, 41, 745-756. [CrossRef]

14. Akinwade, V.O.; Mako, A.A.; Babayemii, O. Biomass yield, chemical composition and the feed potential of water hyacinth (Eichhornia crassipes, Mart. Solms-Laubach) in Nigeria. Int. J. AgriSci. 2013, 3, 659-666.

15. Varanasi, J.L.; Kumari, S.; Das, D. Improvement of energy recovery from water hyacinth by using integrated system. Int. J. Hydrogen Energy 2017, 43, 1303-1318. [CrossRef]

16. Rathod, V.P.; Bhale, P.; Mehta, R.; Harmani, K.; Bilimoria, S.; Mahida, A.; Champaneri, H. Biogas production from water hyacinth in the batch type anaerobic digester. Mater. Today Proc. 2018, 5, 23346-23350. [CrossRef]

17. Poomsawat, W.; Tsalidis, G.; Tsekos, C.; de Jong, W. Experimental studies of furfural production from water hyacinth (Eichhornia Crassipes). Energy Sci. Eng. 2019, 7, 2155-2164. [CrossRef]

18. Sukarni, S.; Zakaria, Y.; Sumarli, S.; Wulandari, R.; Permanasari, A.A.; Suhermanto, M. Physical and chemical properties of water hyacinth (Eichhornia crassipes) as a sustainable biofuel feedstock. IOP Conf. Ser. Mater. Sci. Eng. 2019, 515. [CrossRef]

19. Pushpa, T.B.; Vijayaraghavan, J.; Vijayaraghavan, K.; Jegan, J. Utilization of effective microorganisms based water hyacinth compost as biosorbent for the removal of basic dyes. Desalin. Water Treat. 2016, 57, 24368-24377. [CrossRef]

20. Premalatha, R.P.; Parameswari, E.; Davamani, V.; Malarvizhi, P.; Avudainayagam, S. Biosorption of chromium (III) from aqueous solution by water hyacinth biomass. Madras Agric. J. 2019, 106, 12-21. [CrossRef]

21. Rahman, A.K.M.L.; Al Mamun, R.; Ahmed, N.; Sarkar, A.; Sarkar, A.M. Removal of toxic Congo red dye using water hyacinth petiole, an efficient and selective adsorbent. J. Chem. Soc. Pakistan 2019, 41, 825-833. 
22. Canazart, D.A.; Nunes, A.R.; da, C.; Sanches, M.; Conte, H. Phytoremediation agro industrial wastewater of using macrophyte Eichhornia crassipes. Braz. J. Surg. Clin. Res. BJSCR 2017, 17, 87-91.

23. Gogoi, P.; Adhikari, P.; Maji, T.K. Bioremediation of arsenic from water with citric acid cross-linked water hyacinth (E.crassipes) root powder. Environ. Monit. Assess. 2017, 189. [CrossRef] [PubMed]

24. Nash, D.A.H.; Abdullah, S.R.S.; Hassan, H.A.; Idris, M.; Muhammad, N.F.; Al-baldwi, I.A.; Ismail, N.I. Phytoremediation of nutrients and organic carbon from sago mill effluent using water hyacinth (Eichhornia crassipes). J. Eng. Technol. Sci. 2019, 51, 573-584. [CrossRef]

25. Sayago, U.F.C. Design of a sustainable development process between phytoremediation and production of bioethanol with Eichhornia crassipes. Environ. Monit. Assess. 2019, 191. [CrossRef]

26. De Vasconcelos, G.A.; Véras, R.M.L.; Silva, J. de L.; Cardoso, D.B.; Soares, P. de C.; de Morais, N.N.G.; Souza, A.C. Effect of water hyacinth (Eichhornia crassipes) hay inclusion in the diets of sheep. Trop. Anim. Health Prod. 2016, 48, 539-544. [CrossRef]

27. Mahmood, S.; Khan, N.; Iqbal, K.J.; Ashraf, M.; Khalique, A. Evaluation of water hyacinth (Eichhornia crassipes) supplemented diets on the growth, digestibility and histology of grass carp (Ctenopharyngodon idella) fingerlings. J. Appl. Anim. Res. 2018, 46, 24-28. [CrossRef]

28. Indulekha, V.P.; Thomas, C.G. Utilization of water hyacinth as mulch in turmeric. J. Trop. Agric. 2018, 56, $27-33$.

29. Goswami, L.; Nath, A.; Sutradhar, S.; Bhattacharya, S.S.; Kalamdhad, A.; Vellingiri, K.; Kim, K.-H. Application of drum compost and vermicompost to improve soil health, growth, and yield parameters for tomato and cabbage plants. J. Environ. Manag. 2017, 200, 243-252. [CrossRef]

30. Fan, R.; Luo, J.; Yan, S.; Wang, T.; Liu, L.; Gao, Y.; Zhang, Z. Use of water hyacinth (eichhornia crassipes) compost as a peat substitute in soilless growth media. Compost Sci. Util. 2015, 23, 237-247. [CrossRef]

31. Liu, X.; Zu, X.; Liu, Y.; Sun, L.; Yi, G.; Lin, W.; Wu, J. Conversion of waste water hyacinth into high-value chemicals by iron (III) chloride under mild conditions. BioResources 2018, 13, 2293-2303. [CrossRef]

32. Salas-Ruiz, A.; Barbero-Barrera, M. del M.; Ruiz-Téllez, T. Microstructural and thermo-physical characterization of a Water Hyacinth petiole for thermal insulation particle board manufacture. Materials 2019, 12, 560. [CrossRef] [PubMed]

33. Kurup, R.S.C.; Snishamol, C.; Prabhu, G.N. Cellulase Production by native bacteria using water hyacinth as substrate under solid state fermentation. Malays. J. Microbiol. 2005, 1, 25-29. [CrossRef]

34. Karmakar, M.; Ray, R.R. A Statistical approach for optimization of simultaneous production of $\beta$-glucosidase and endoglucanase by rhizopus oryzae from solid-state fermentation of water hyacinth using central composite design. Biotechnol. Res. Int. 2011, 2011, 574983. [CrossRef] [PubMed]

35. Udeh, C.B.; Ameh, J.B.; Ado, S.A.; Okoduwa, S.I.R. Optimization of xylanase production from fermentation of water hyacinth (Eichhornia crassipes) using Trichoderma species. J. Biotechnol. Res. 2017, 3, 2413-3256.

36. Lalitha, P.; Sripathi, S.K.; Jayanthi, P. Secondary metabolites of Eichhornia crassipes (Waterhyacinth): A review (1949 to 2011). Nat. Prod. Commun. 2012, 7, 1249-1256. [CrossRef]

37. Saratale, R.G.; Cho, S.K.; Ghodake, G.S.; Shin, H.S.; Saratale, G.D.; Park, Y.; Lee, H.S.; Bharagava, R.N.; Kim, D.S. Utilization of noxious weed water hyacinth biomass as a potential feedstock for biopolymers production: A novel approach. Polymers 2020, 12, 1704. [CrossRef]

38. Sundari, M.T.; Ramesh, A. Isolation and characterization of cellulose nanofibers from the aquatic weed water hyacinth-Eichhornia crassipes. Carbohydr. Polym. 2012, 87, 1701-1705. [CrossRef]

39. Setyaningsih, L.; Satria, E.; Khoironi, H.; Dwisari, M.; Setyowati, G.; Rachmawati, N.; Kusuma, R.; Anggraeni, J. Cellulose extracted from water hyacinth and the application in hydrogel. IOP Conf. Ser. Mater. Sci. Eng. 2019, 673. [CrossRef]

40. Rezania, S.; Din, M.F.M.; Kamaruddin, S.F.; Taib, S.M.; Singh, L.; Yong, E.L.; Dahalan, F.A. Evaluation of water hyacinth (Eichhornia crassipes) as a potential raw material source for briquette production. Energy 2016, 111, 768-773. [CrossRef]

41. Zhang, Q.; Wei, Y.; Han, H.; Weng, C. Enhancing bioethanol production from water hyacinth by new combined pretreatment methods. Bioresour. Technol. 2018, 251, 358-363. [CrossRef]

42. Priya, P.; Nikhitha, S.O.; Anand, C.; Nath, R.S.D.; Krishnakumar, B. Biomethanation of water hyacinth biomass. Bioresour. Technol. 2018, 255, 288-292. [CrossRef] [PubMed]

43. Barua, V.B.; Goud, V.V.; Kalamdhad, A.S. Microbial pretreatment of water hyacinth for enhanced hydrolysis followed by biogas production. Renew. Energy 2018, 126, 21-29. [CrossRef] 
44. Sarto, S.; Hildayati, R.; Syaichurrozi, I. Effect of chemical pretreatment using sulfuric acid on biogas production from water hyacinth and kinetics. Renew. Energy 2019, 132, 335-350. [CrossRef]

45. Mathew, A.K.; Bhui, I.; Banerjee, S.N.; Goswami, R.; Chakraborty, A.K.; Shome, A.; Balachandran, S.; Chaudhury, S. Biogas production from locally available aquatic weeds of Santiniketan through anaerobic digestion. Clean Technol. Environ. Policy 2015, 17, 1681-1688. [CrossRef]

46. Hernández-Shek, M.A.; Cadavid-Rodríguez, L.S.; Bolaños, I.V.; Agudelo-Henao, A.C. Recovering biomethane and nutrients from anaerobic digestion of water hyacinth (Eichhornia crassipes) and its co-digestion with fruit and vegetable waste. Water Sci. Technol. 2016, 73, 355-361. [CrossRef]

47. Singh, J.; Kalamdhad, A.S. Reduction of bioavailability and leachability of heavy metals during vermicomposting of water hyacinth. Environ. Sci. Pollut. Res. 2013, 20, 8974-8985. [CrossRef] [PubMed]

48. Grand View Research. Industrial Enzymes Market Size, Share \& Trends Analysis Report by Product (Carbohydrases, Proteases, Lipases, Polymerases E Nucleases), by Source, by Application, By Region, and Segment Forecasts, 2020-2027; Grand View Research: San Francisko, CA, USA, 2020; Available online: https://www.grandviewresearch. com/industry-analysis/industrial-enzymes-market/methodology (accessed on 2 October 2020).

49. Harun, M.Y.; Dayang Radiah, A.B.; Zainal Abidin, Z.; Yunus, R. Effect of physical pretreatment on dilute acid hydrolysis of water hyacinth (Eichhornia crassipes). Bioresour. Technol. 2011, 102, 5193-5199. [CrossRef]

50. Bhui, I.; Mathew, A.K.; Chaudhury, S.; Balachandran, S. Influence of volatile fatty acids in different inoculum to substrate ratio and enhancement of biogas production using water hyacinth and salvinia. Bioresour. Technol. 2018, 270, 409-415. [CrossRef]

51. Arp, R.S.; Fraser, G.C.G.; Hill, M.P. Quantifying the economic water savings benefit of water hyacinth (Eichhornia crassipes) control in the vaalharts irrigation scheme. Water SA 2017, 43, 58-66. [CrossRef]

52. Van Wilgen, B.W.; Richardson, D.M.; Le Maitre, D.C.; Marais, C.; Magadlela, D. The economic consequences of alien plant invasions: Examples of impacts and approaches to sustainble management in South Africa. Environ. Dev. Sustain. 2001, 3, 145-168. [CrossRef]

53. Zachariades, C.; Paterson, I.D.; Strathie, L.W.; Hill, M.P.; van Wilgen, B.W. Assessing the status of biological control as a management tool for suppression of invasive alien plants in South Africa. Bothalia 2017, 47, 1-19. [CrossRef]

54. Fraser, G.C.G.; Hill, M.P.; Martin, J.A. Economic evaluation of water loss saving due to the biological control of water hyacinth at New Year's Dam, Eastern Cape province, South Africa. Afr. J. Aquat. Sci. 2016, 41, 227-234. [CrossRef]

55. De Groote, H.; Ajuonu, O.; Attignon, S.; Djessou, R.; Neuenschwander, P. Economic impact of biological control of water hyacinth in Southern Benin. Ecol. Econ. 2003, 45, 105-117. [CrossRef]

56. Garlich, N.; Guarnieri, C.C.O.; Freitas, R.L.G.; Cervoni, J.H.C.; Cruz, C.; Ferreira, M.C. Efficacy of imazamox with centrifugal energy spray nozzle on eichhornia crassipes and economic analysis of control viability. Planta Daninha 2019, 37. [CrossRef]

57. Wainger, L.A.; Harms, N.E.; Magen, C.; Liang, D.; Nesslage, G.M.; McMyrray, M.; Cofrancesco, A.F. Evidence-based economic analysis demonstrates that ecosystem service benefits of water hyacinth management greatly exceed research and control costs. PeerJ 2018, 2018, e4824. [CrossRef]

58. Wang, Z.; Calderon, M.M. Environmental and economic analysis of application of water hyacinth for eutrophic water treatment coupled with biogas production. J. Environ. Manag. 2012, 110, 246-253. [CrossRef]

59. Bentzen, J.; Truc, N.T.T.; Nam, T.S. A social cost-benefit analysis of biogas technologies using rice straw and water hyacinths as feedstock. Int. Energy J. 2018, 18, 311-320.

60. Wang, Z.; Zheng, F.; Xue, S. The economic feasibility of the valorization of water hyacinth for bioethanol production. Sustainability 2019, 11, 905. [CrossRef]

61. Hudakorn, T.; Kitjettanee, C.; Sritrakul, N.; Jaruyanon, P. A feasibility study of continuous stirred tank reactor (CSTR) biogas network from water hyacinth at Hin Moon. In Proceedings of the 7th International Electrical Engineering Congress (iEECON), Hua Hin, Thailand, 6-8 March 2019; pp. 1-4.

62. Laitinen, J.; Moliis, K.; Surakka, M. Resource efficient wastewater treatment in a developing area-Climate change impacts and economic feasibility. Ecol. Eng. 2017, 103, 217-225. [CrossRef]

63. Hronich, J.E.; Martin, L.; Plawsky, J.; Bungay, H.R. Potential of Eichhornia crassipes for biomass refining. J. Ind. Microbiol. Biotechnol. 2008, 35, 393-402. [CrossRef] 
64. Buller, L.S.; Ortega, E.; Bergier, I.; Mesa-Pérez, J.M.; Salis, S.M.; Luengo, C.A. Sustainability assessment of water hyacinth fast pyrolysis in the Upper Paraguay River basin, Brazil. Sci. Total Environ. 2015, 532, $281-291$. [CrossRef]

65. Pfau, S.F.; Hagens, J.E.; Dankbaar, B. Biogas between renewable energy and bio-economy policies-Opportunities and constraints resulting from a dual role. Energy Sustain. Soc. 2017, 7, 17. [CrossRef]

66. International Renewable Energy Agency (IRENA). Renewable Energy in the Water, Energy and Food Nexus; International Renewable Energy Agency: Abu Dhabi, UAE, 2015; pp. 1-125.

67. International Renewable Energy Agency (IRENA). Southern African Power Pool: Planning and Prospects for Renewable Energy; International Renewable Energy Agency: Abu Dhabi, UAE, 2013; pp. 1-91.

68. Rezania, S.; Ponraj, M.; Din, M.F.M.; Songip, A.R.; Sairan, F.M.; Chelliapan, S. The diverse applications of water hyacinth with main focus on sustainable energy and production for new era: An overview. Renew. Sustain. Energy Rev. 2015, 41, 943-954. [CrossRef]

69. Kriticos, D.J.; Brunel, S. Assessing and managing the current and future pest risk from water hyacinth, (Eichhornia crassipes), an invasive aquatic plant threatening the environment and water security. PLoS ONE 2016, 11, e0120054. [CrossRef]

70. Okudoh, V.; Trois, C.; Workneh, T.; Schmidt, S. The potential of cassava biomass and applicable technologies for sustainable biogas production in South Africa: A review. Renew. Sustain. Energy Rev. 2014, 39, 1035-1052. [CrossRef]

Publisher's Note: MDPI stays neutral with regard to jurisdictional claims in published maps and institutional affiliations.

(C) 2020 by the authors. Licensee MDPI, Basel, Switzerland. This article is an open access article distributed under the terms and conditions of the Creative Commons Attribution (CC BY) license (http://creativecommons.org/licenses/by/4.0/). 